\title{
Spot sign and live-imaged dramatic intracerebral hematoma expansion
}

\section{Figure CT scans}
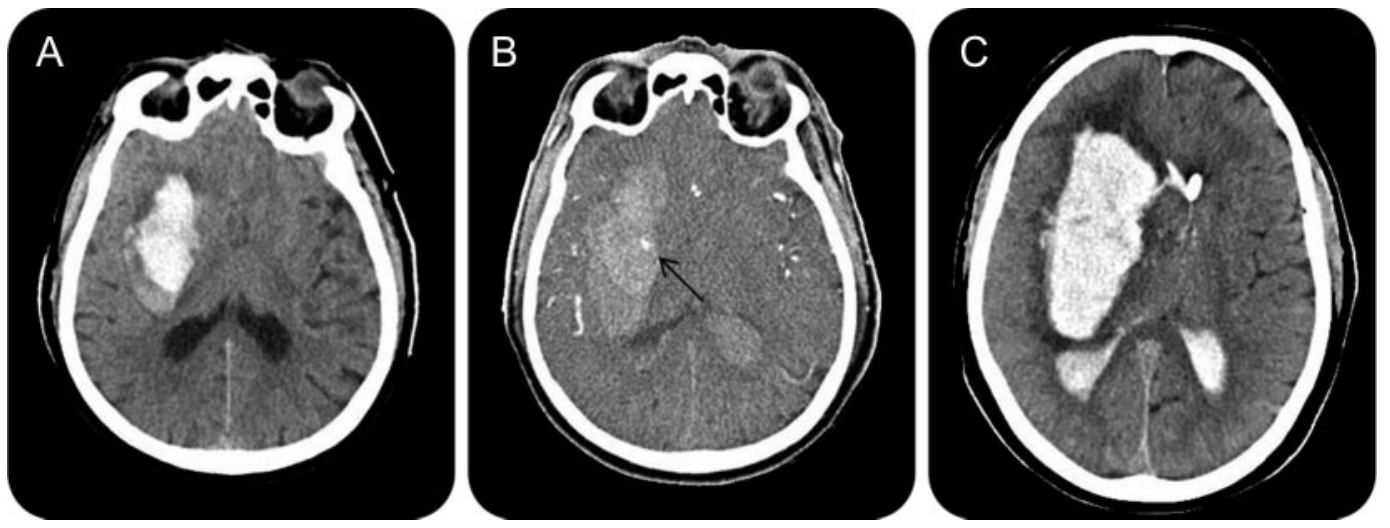

Baseline noncontrast CT shows heterogeneous right deep parenchymal hemorrhage (A). Subsequent CT angiography demonstrates hematoma progression with significant enlargement and new intraventricular extension. A small focus of enhancement is seen within the lesion consistent with spot sign (B) (arrow). Control noncontrast CT shows increased size of the hemorrhage with substantial mass effect, subfalcine herniation, and midline shift (C).

A 74-year-old man with a history of hypertension presented 1 hour after a sudden onset of a complete right hemisphere syndrome. Noncontrast CT showed a 43-mL right deep intracranial hematoma (figure, A). CT angiography (CTA) performed 10 minutes later, as per our imaging protocol, detected a dramatic hematoma growth up to $84 \mathrm{~mL}$, together with intraventricular extension. A spot sign was apparent (figure, B). By the end of CT scanning, the patient's Glasgow Coma Scale score had dropped to 7. Follow-up CT scan confirmed further hematoma expansion as predicted by the spot sign (figure, C).

The spot sign, defined as 1-mm to 2-mm foci of enhancement within a hematoma on CTA source images, is typically located in the periphery of hematomas and suggests the likelihood of expansion. The pathologic basis remains unclear, but may represent primary vessel pathology such as microaneurysms. ${ }^{1}$ Alternatively, extravasation of blood within the hematoma could occur, as suggested by slow expansion within the hematoma after contrast, ${ }^{2}$ possibly due to secondary vessel disruption by the hematoma. In our case, the spot sign was already present when the hematoma was expanding and predicted further growth, supporting the mechanism of extravasation and contrast leakage related to secondary vessel damage.

\section{P. García Bermejo, MD, J. Arribas García, MD, S. Pérez-Fernández, MD, J.F. Arenillas, MD, PhD, Valladolid, Spain}

Disclosure: Dr. García Bermejo, Dr. Arribas García, and Dr. Pérez-Fernández report no disclosures. Dr. Arenillas has received funding for travel or speaker honoraria from Grupo Ferrer Internacional S.A., Pfizer Inc., Lundbeck, Inc., Merck \& Co., Inc., and SanofiAventis; serves on the editorial advisory board of Neurologia; and receives research support from Pfizer Inc., Sanofi-Aventis, Lundbeck, Inc., BrainsGate, Grupo Ferrer Internacional S.A., the Spanish Ministry of Health, the Spanish Ministry of Science (Carlos III Institute of Health and Health Department of Castile-Lion, Spain), the Spanish Ministry of Education, and the Spanish Ministry of Technology.

Address correspondence and reprint requests to Dr. Pablo García Bermejo, Stroke Unit, Department of Neurology, Hospital Clinico Universitario, Avda. Ramón y Cajal 3, 47005 Valladolid, Spain; pablerah@hotmail.com

1. Wada R, Aviv RI, Fox AJ, et al. CT angiography “spot sign” predicts hematoma expansion in acute intracerebral hemorrhage. Stroke 2007;38:1257-1262.

2. Ederies A, Demchuk A, Chia T, et al. Postcontrast CT extravasation is associated with hematoma expansion in CTA spot negative patients. Stroke 2009;40:1672-1676. 


\section{Neurology}

\section{Spot sign and live-imaged dramatic intracerebral hematoma expansion \\ P. García Bermejo, J. Arribas García, S. Pérez-Fernández, et al. \\ Neurology 2010;75;834 \\ DOI 10.1212/WNL.0b013e3181f07074}

This information is current as of August 30, 2010

\section{Updated Information \& Services}

References

Citations

Subspecialty Collections

Permissions \& Licensing

Reprints including high resolution figures, can be found at: http://n.neurology.org/content/75/9/834.full

This article cites 2 articles, 2 of which you can access for free at: http://n.neurology.org/content/75/9/834.full\#ref-list-1

This article has been cited by 2 HighWire-hosted articles: http://n.neurology.org/content/75/9/834.full\#\#otherarticles

This article, along with others on similar topics, appears in the following collection(s):

All Cerebrovascular disease/Stroke

http://n.neurology.org/cgi/collection/all_cerebrovascular_disease_strok e

Coma

http://n.neurology.org/cgi/collection/coma

CT

http://n.neurology.org/cgi/collection/ct

Intracerebral hemorrhage

http://n.neurology.org/cgi/collection/intracerebral_hemorrhage

Information about reproducing this article in parts (figures,tables) or in its entirety can be found online at:

http://www.neurology.org/about/about_the_journal\#permissions

Information about ordering reprints can be found online:

http://n.neurology.org/subscribers/advertise

Neurology ${ }^{\circledR}$ is the official journal of the American Academy of Neurology. Published continuously since 1951, it is now a weekly with 48 issues per year. Copyright . All rights reserved. Print ISSN: 0028-3878. Online ISSN: 1526-632X.

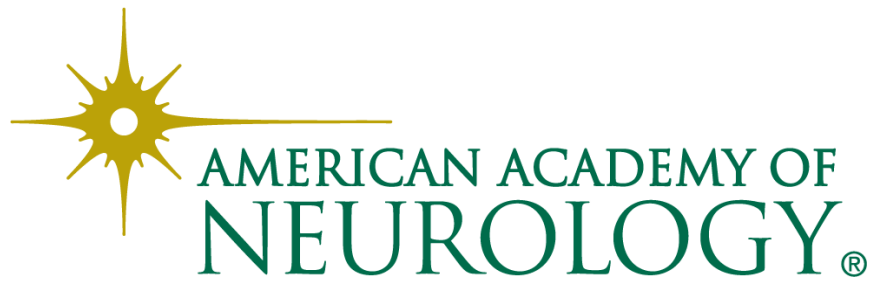

